\title{
Studi Kesenjangan Motif dan Kepuasan Followers dalam Mengikuti Akun @ tmcpoldametro di Instagram
}

\author{
Nathania, Farid Rusdi \\ nathaniarachell@gmail.com, farid@fikom.untar.ac.id \\ Fakultas Ilmu Komunikasi Universitas Tarumanagara
}

\begin{abstract}
Traffic Management Centre (TMC) Polda Metro Jaya is an essential counterpart of the Indonesian traffic management system that functions in distributing information regarding traffic conditions to the society. TMC Polda Metro Jaya was first pioneered on 1997 using call centre systems, it then started a major development through social media, with Instagram as one of the platforms it uses. TMC Polda Metro Jaya's Instagram account, now known widelyas @tmcpoldametro becomes an interesting research material as it is one of many accounts that is bound to deliver on-the-record information from government agencies. This research aims to discover the strongest motive that is affecting @tmcpoldametro's followers and their satisfactions subsequent to following the account. This research uses quantitative method. The population used in this research are the followers of @ tmcpoldametrowhich are 447.100 accounts in total, with the sample of 100 respondents. The result of this research shows that the highest satisfaction is none other than informational satisfaction, accentuated by the statement "able to gain information about occurrences around our environment", while the lowest satisfaction are the integrated satisfaction and social interactions, pointed out by the statement of "able to append social empathy". In overall, there are discrepancy between the motives and satisfaction that followers get in following @ tmcpoldametro account in Instagram. Most of the respondents are satisfied, and even, highly satisfied after following the @ tmcpoldametro Instagram account.
\end{abstract}

Keyword: Social Media, Instagram, Gratification Sought, Gratification Obtained

\begin{abstract}
Abstrak
Traffic Management Center (TMC) Polda Metro Jaya merupakan salah satu bagian penting dalam mendistribusikan informasi mengenai kondisi lalu lintas kepada masyarakat. TMC Polda Metro Jaya awalnya dirintis pada 1997 melalui call center, namun sekarang sudah berkembang melalui media sosial, salah satunya Instagram. Akun Instagram @ tmcpoldametro menarik untuk diteliti karena merupakan salah satu akun yang menyampaikan informasi resmi dari instansi negara. Penelitian ini bertujuan untuk mengetahui motif terkuat yang mempengaruhi para followers serta tingkat kepuasan followers setelah mengikuti akun @ tmcpoldametro. Penelitian dilakukan dengan pendekatan kuantitatif, dengan menggunakan metode survei. Populasi dalam penelitian ini adalah followers @ tmcpoldametro yang saat ini berjumlah 447.100 akun dengan sampel 100 responden. Hasil penelitian menunjukkan bahwa kepuasan tertinggi adalah kepuasan informasi, sedangkan kepuasan terendah adalah kepuasan integrasi dan interaksi sosial. Secara keseluruhan, terdapat kesenjangan antara motif dan kepuasan yang didapatkan followers dalam mengikuti akun @ tmcpoldametro di Instagram. Sebagian besar responden merasa puas bahkan sangat puas setelah mengikuti akun Instagram @ tmcpoldametro.
\end{abstract}

Kata kunci: Media Sosial, Instagram, Motif, Kepuasan 


\section{Pendahuluan}

Media saat ini sangat berkembang pesat, sehingga mendorong manusia untuk memanfaatkan perkembangan teknologi, khususnya teknologi internet. Menurut hasil survei yang dilakukan oleh Asosiasi Penyelenggara Jasa Internet Indonesia (APJII) tahun 2017, sudah 54,68\% penduduk Indonesia (143,26 juta jiwa dari 262 juta jiwa) menggunakan internet. Hasil survei juga menunjukkan meningkatnya angka pengguna internet setiap tahunnya. Penggunaan media berbasis internet (new media) pada zaman sekarang lebih sering dipakai, karena berbagai kemudahan new media, seperti biaya yang relatif murah, serta kemudahan dan kecepatan dalam mengakses informasi.

Media baru (new media) adalah media yang berbasis internet dengan menggunakan komputer dan telepon genggam canggih (Carey dalam McQuail, 2011). Ciri utama media baru adalah adanya saling keterhubungan antara akses khalayak individu sebagai penerima maupun pengirim pesan, interaktivitas, kegunaan yang beragam, dan sifatnya yang ada dimana-mana (McQuail, 2011).

Salah satu jenis new media yang juga banyak digunakan orang saat ini ialah aplikasi media sosial. Media sosial adalah media yang banyak digunakan oleh masyarakat untuk berkomunikasi. Media sosial memiliki fungsi untuk dapat mendukung interaksi sosial bagi para penggunanya. Salah satu media sosial yang berkembang sangat pesat adalah Instagram, yaitu aplikasi untuk mengirimkan secara cepat informasi dalam bentuk foto serta keterangan gambar. Dalam Instagram, kita dapat mengelola foto yang akan dibagikan, mengedit foto, dan membagikan ke sesama pengguna Instagram maupun media sosial yang lain.

Menurut TechCrunch (2018), Instagram sekarang sudah menembus satu miliar jumlah pengguna aktif bulanan (Monthly Active User), dan pertumbuhannya lebih signifikan dibandingkan Facebook dan Snapchat. Snapchat memiliki pertumbuhan per kuartal 2,13 persen, Facebook 3,14 persen, sedangkan Instagram pertumbuhannya mencapai 5 persen per kuartal. Instagram juga merupakan salah satu dari sepuluh besar media sosial yang aktif di Indonesia menurut survei WeAreSocial.

Pengguna media sosial memiliki motif masing-masing untuk memilih konten apa yang ingin mereka konsumsi di Instagram. Hal ini menunjukkan konsep dari teori Uses and Gratifications yang dinyatakan oleh Katz dan Blumler untuk menjelaskan pemilihan serta penggunaan media yang dilakukan khalayak. Menurut teori ini, khalayak atau pengguna media memiliki peran aktif dalam mencari media tertentu dan isi (muatan) tertentu untuk memenuhi kebutuhan atau menghasilkan kepuasan tertentu (West and Turner, 2013).

Salah satu jenis riset mengenai uses and gratification yang berkembang saat ini dibuat oleh Philip Palmgreen dari Kentucky University. Dalam model ini, yang ditanyakan adalah apakah motif khalayak dalam menggunakan media telah dapat dipenuhi oleh media, atau apakah khalayak puas setelah menggunakan media. Dalam hal ini yang perlu diukur adalah Gratification Sought (GS) atau kepuasan yang diinginkan dan Gratification Obtained $(G O)$ atau kepuasan yang diperoleh (Kriyantono, 2012).

Sebagai media sosial, Instagram juga dimanfaatkan untuk menjadi sarana berbagi informasi. Sekarang ini, Instagram memiliki berbagai macam kegunaan seperti untuk membuat online shop, akun hiburan, akun resmi perusahaan, penyedia jasa, dan berbagai komunitas dan instansi resmi maupun tidak resmi (Ma'ruf, Moh.Ali, 2017). Salah satu akun yang menyampaikan informasi resmi dari instansi negara adalah akun 
Instagram Polda Metro Jaya (@tmcpoldametro), yang merupakan akun Traffic Management Center (TMC) dari Kepolisian Daerah Metropolitan Jakarta Raya.

TMC Polda Metro Jaya merupakan salah satu bagian penting dalam kepolisian karena berguna untuk mendistribusikan informasi kepada masyarakat mengenai kondisi lalu lintas. TMC Polda Metro Jaya sendiri dirintis tahun 1997. Awalnya, informasi disebarkan hanya melalui call center 1717, namun sekitar tahun 2008 mulai dirintis upaya distribusi informasi melalui media sosial, salah satunya Instagram (megapolitan.kompas.com, 6 Juni 2018).

Adapun dalam penelitian ini penulis merumuskan masalah yaitu sejauh mana tingkat kesenjangan motif dan kepuasan followers setelah mengikuti akun @ tmcpoldametro di Instagram?. Hipotesis yang diangkat yaitu tidak ada kesenjangan antara motif dan kepuasan yang didapatkan followers dalam mengikuti akun @ tmcpoldametro di Instagram, dan ada kesenjangan antara motif dan kepuasan yang didapatkan followers dalam mengikuti akun@tmcpoldametro di Instagram. Tujuan dari penelitian ini adalah untuk mengetahui tingkat kesenjangan motif dan kepuasan followers setelah mengikuti akun @ tmcpoldametro di Instagram.

\section{Metode Penelitian}

Penelitian yang akan digunakan adalah penelitian kuantitatif, yaitu penelitian yang menggambarkan atau menjelaskan suatu masalah yang hasilnya dapat digeneralisasikan. (Kriyantono, 2012).

Metode yang digunakan adalah metode survei deskriptif dan eksplanatif. Metode survei deskriptif digunakan untuk mendeskripsikan populasi yang sedang diteliti dengan menggunakan kuisioner (Kriyantono, 2012). Penelitian ini mendeskripsikan tingkat kepuasan followers akun Instagram @tmcpoldametro setelah mengikuti akun tersebut. Sedangkan metode survei eksplanatif yang digunakan adalah komparatif, yaitu untuk membandingkan dan mengetahui mengapa situasi atau kondisi tertentu terjadi (Kriyantono, 2012), yaitu untuk membandingkan motif dan kepuasan followers akun Instagram @ tmcpoldametro setelah mengikuti akun tersebut.

Data dikumpulkan menggunakan metode survei, yaitu riset dengan menggunakan kuesioner sebagai instrumen pengumpulan data. Tujuannya untuk memperoleh informasi tentang sejumlah responden yang dianggap mewakili populasi tertentu. (Kriyantono, 2012)

Dalam penelitian ini, akan digunakan kuisioner tertutup, yaitu suatu kuisioner dimana responden telah diberikan alternatif jawaban oleh periset. Responden tinggal memilih jawaban yang menurutnya sesuai dengan realitas yang dialaminya (Kriyantono, 2012). Kuesioner akan dibagikan melalui direct message dan mendatangi responden secara langsung.

Peneliti melakukan survei terhadap followers akun Instagram @tmcpoldametro yang berpopulasi 447.100 orang. Untuk menentukan jumlah sampel, digunakan rumus Slovin dan didapatkan hasil yaitu:

$$
n=99.98 \text { orang }
$$

Sampel dibulatkan menjadi 100 orang dari 447.100 followers akun Instagram @ tmcpoldametro. 
Adapun indikator dari motif yang diteliti adalah sebagai berikut:

1. Ingin mengetahui informasi dan peristiwa di lingkungan sekitar

2. Ingin memberi dan menerima komentar

3. Ingin memperoleh pengetahuan baru

4. Ingin mengekspresikan diri

5. Ingin memperoleh nilai lebih sebagai pengguna Instagram

6. Ingin melakukan interaksi sosial dengan orang lain

7. Ingin menambah rasa empati sosial

8. Ingin menyalurkan emosi

9. Ingin bersantai dan mengisi waktu luang

10. Ingin memperoleh hiburan dan kesenangan

Indikator dari kepuasan yang diteliti adalah sebagai berikut:

1. Dapat mengetahui informasi dan peristiwa di lingkungan sekitar

2. Dapat memberi dan menerima komentar

3. Dapat memperoleh pengetahuan baru

4. Dapat mengekspresikan diri

5. Dapat memperoleh nilai lebih sebagai pengguna Instagram

6. Dapat melakukan interaksi sosial dengan orang lain

7. Dapat menambah rasa empati sosial

8. Dapat menyalurkan emosi

9. Dapat bersantai dan mengisi waktu luang

10. Dapat memperoleh hiburan dan kesenangan

\section{Hasil Temuan dan Diskusi}

Tingkat kesenjangan setiap dimensi akan diukur melalui tabel-tabel berikut dengan keterangan notasi X dan Y sebagai variabel, notasi huruf A-D sebagai dimensi dan 1-10 sebagai butir pernyataan. Jika persentase kesenjangan bernilai 21-30\% maka tingkat kepuasan rendah, 11-20\% maka tingkat kepuasan sedang, 0-10\% maka tingkat kepuasan tinggi (Wibowo, 2015).

Tabel 1. Hasil Penghitungan Discrepancy / Kesenjangan

\begin{tabular}{lcc}
\hline \multicolumn{1}{c}{ Indikator } & $\begin{array}{c}\text { Persentase } \\
\text { Kesenjangan }\end{array}$ & $\begin{array}{c}\text { Tingkat } \\
\text { Kepuasan }\end{array}$ \\
\hline $\begin{array}{l}\text { Dapat mengetahui informasi dan peristiwa di lingkungan } \\
\text { sekitar }\end{array}$ & $13 \%$ & Sedang \\
Dapat memberi dan menerima komentar & $15 \%$ & Sedang \\
Dapat memperoleh pengetahuan baru & $17 \%$ & Sedang \\
Dapat mengekspresikan diri & $17 \%$ & Sedang \\
Dapat memperoleh nilai lebih sebagai pengguna Instagram & $26 \%$ & Rendah \\
Dapat melakukan interaksi sosial dengan orang lain & $20 \%$ & Sedang \\
Dapat menambah rasa empati sosial & $28 \%$ & Rendah \\
Dapat menyalurkan emosi & $17 \%$ & Sedang \\
Dapat bersantai dan mengisi waktu luang & $18 \%$ & Sedang \\
Dapat memperoleh hiburan dan kesenangan & $20 \%$ & Sedang \\
\hline Sumber: Hasil Pengolan
\end{tabular}

Sumber: Hasil Pengolahan Data di SPSS versi 21

Berdasarkan tabel diatas, dapat disimpulkan bahwa kepuasan tertinggi terdapat pada indikator XA1-YA1 yaitu pada pernyataan "dapat memperoleh informasi dan 
peristiwa di lingkungan sekitar". Kepuasan terendah terdapat pada indikator XC2-YC2 yaitu pada pernyataan "dapat menambah rasa empati sosial".

Tabel 2. Perbandingan Mean

\begin{tabular}{lccc}
\hline \multicolumn{1}{c}{ Dimensi } & GS & GO & GD \\
\hline Informasi & 3.62 & 4.30 & 0.68 \\
Identitas Pribadi & 2.87 & 3.36 & 0.49 \\
Integrasi dan Interaksi Sosial & 3.45 & 3.78 & 0.33 \\
Hiburan & 3.11 & 3.65 & 0.54 \\
$\quad$ Perbandingan Mean Variabel & $\mathbf{3 . 2 6}$ & $\mathbf{3 . 7 7}$ & $\mathbf{0 . 5 1}$ \\
\hline
\end{tabular}

Keterangan: GS = Gratification Sought/Motif, GO = Gratification

Obtained/Kepuasan, GD = Gratification Discrepancy/Kesenjangan

Sumber: Hasil Pengolahan Data di SPSS versi 21

Berdasarkan tabel tersebut, dapat dilihat bahwa nilai mean GO dari setiap dimensi selalu lebih besar (>) dibandingkan nilai mean GS. Hal ini menandakan bahwa followers akun Instagram @tmcpoldametro puas dalam semua dimensi. Secara keseluruhan, nilai mean GO lebih besar (>) dibandingkan nilai mean GS, dengan tingkat kesenjangan sebesar 0.51. Hal tersebut berarti secara keseluruhan followers akun Instagram @tmcpoldametro puas setelah mengikuti akun tersebut. Karena adanya kesenjangan maka $\mathrm{H} 1$ diterima, yaitu ada kesenjangan antara motif dan kepuasan yang didapatkan followers dalam mengikuti akun @tmcpoldametro di Instagram.

Kepuasan terbesar terdapat pada kepuasan Informasi, dengan kesenjangan 0.68. Banyak informasi baru yang dapat diperoleh followers melalui akun Instagram @ tmcpoldametro.

Pada analisis koefisien korelasi, ditemukan adanya hubungan positif antara GS dan GO, artinya bila GS naik, maka GO juga naik, dan berlaku juga sebaliknya. Melalui uji T dua sampel berpasangan (Paired Sampled T-Test), didapatkan adanya perbedaan signifikan antara GS dengan GO.

Analisis

Menurut data dari HypeAuditor (2018), mayoritas followers akun Instagram $@$ tmcpoldametro berlokasi di Indonesia (85\%), tepatnya Jakarta (42\%). Hal ini terjadi karena informasi yang disampaikan oleh akun ini mayoritas seputar lalu lintas di Jakarta, karena merupakan akun bagian dari Kepolisian Daerah Metropolitan Jakarta Raya. Selain itu, ditemukan juga fakta bahwa followers akun Instagram @ tmcpoldametro lebih banyak Pria (68\%) dibandingkan Wanita (32\%), serta mayoritas usia 18-24 tahun dan 25-34 tahun.

Peneliti melakukan penelitian kesenjangan dua variabel yaitu Motif / Gratification Sought (X) dan Kepuasan / Gratification Obtained (Y) followers setelah mengikutiakun@tmcpoldametro di Instagram. Berdasarkan data statistik, diketahui bahwa terdapat kesenjangan antara motif dengan kepuasan followers, hal ini diketahui dengan lebih besarnya rata-rata tingkat kepuasan followers dibandingkan rata-rata motif mengikuti akun tersebut. Karena angka kepuasan yang diperoleh lebih besar daripada kepuasan yang dicari, maka dapat disimpulkan bahwa followers merasa puas bahkan sangat puas. Adanya kesenjangan juga berarti hipotesis H1 diterima, yaitu ada kesenjangan antara motif dan kepuasan followers dalam mengikuti akun @ tmcpoldametro di Instagram. 
Informasi merupakan alasan terpenting dari terbentuknya media sosial @ tmcpoldametro, yaitu untuk memberikan informasi mengenai kondisi lalu lintas. Alasan ini terpenuhi karena terlihat bahwa followers paling tinggi tingkat kesenjangannya dalam kepuasan informasi (0.68), dengan kepuasan yang paling tinggi nilainya pada pernyataan "dapat mengetahui informasi dan peristiwa di lingkungan sekitar". Melalui hasil tersebut dapat disimpulkan bahwa followers merasa puas dalam mendapatkan informasi-informasi lalu lintas.

Selain mengenai pemenuhan motif Informasi, masyarakat juga ternyata cukup puas dari segi Hiburan, dengan pernyataan yang paling tinggi nilai kepuasannya yaitu "dapat menyalurkan emosi". Hal ini terlihat dengan beradanya kepuasan Hiburan di peringkat kedua tingkat kesenjangannya. Dengan mengetahui informasi berupa fakta dari Polda Metro Jaya serta berdiskusi dengan sesama followers, mereka dapat saling menyalurkan emosi. Tentunya diskusi ini dipermudah karena dalam media sosial, followers dengan mudah memberikan feedback yang tentunya juga dapat bermanfaat untuk Polda Metro Jaya sendiri. Followers dapat mengomentari informasi yang mereka dapatkan di postingan Instagram @ tmcpoldametro.

Dengan berbagai posisi followers seperti hanya sekedar pembaca informasi hingga pembaca aktif yang ikut memberikan komentar-komentar atau feedback, tentunya followers juga dapat lebih mengenal identitas pribadinya. Kepuasan Identitas Pribadi berada di peringkat ketiga nilai kesenjangannya dengan pernyataan paling tinggi kepuasannya yaitu "dapat mengekspresikan diri".

Media digital juga sangat membantu lebih efisiennya penyebaran informasi serta mempermudah komunikasi. Dengan peralihan dari call center ke media sosial Instagram, @tmcpoldametro telah menggunakan peluangnya untuk lebih cepat menyebarkan informasi, serta memiliki lebih banyak audiens dan berinteraksi lebih dekat dengan followersnya. Namun, kepuasan Integrasi dan Interaksi sosial berada di peringkat keempat nilai kesenjangannya dengan pernyataan paling tinggi tingkat kepuasannya yaitu "dapat melakukan interaksi sosial dengan orang lain". Hal ini disebabkan karena orang yang memberikan feedback hanya pada postingan yang menurut mereka menarik, sehingga lingkup bertemu orang-orang baru hanya tergantung minat followers.

\section{Simpulan}

Dalam uji Discrepancy dan perbandingan mean, ditemukan bahwa kepuasan tertinggi adalah kepuasan Informasi dengan kesenjangan 0.68 , khususnya pada pernyataan "dapat mengetahui informasi dan peristiwa di lingkungan sekitar" sebesar $13 \%$, sedangkan kepuasan terendah terdapat pada kepuasan Integrasi dan Interaksi Sosial dengan kesenjangan 0.33 khususnya pada pernyataan "dapat menambah rasa empati sosial" sebesar 28\%. Adanya kesenjangan juga menandakan bahwa Hipotesis H1 diterima, yaitu ada kesenjangan antara motif dan kepuasan yang didapatkan followers dalam mengikuti akun @ tmcpoldametro di Instagram.

Rata-rata keseluruhan motif dan kepuasan menggambarkan adanya kesenjangan sebesar 0.51 karena kepuasan yang diperoleh (3.77) lebih besar (>) dari motif (3.26), artinya setelah mengikuti akun Instagram @tmcpoldametro, followers merasa puas bahkan sangat puas.

Pada analisis koefisien korelasi, ditemukan adanya hubungan positif antara GS dan GO, artinya bila GS naik, maka GO juga naik, dan berlaku juga sebaliknya. 
Melalui uji T dua sampel berpasangan (Paired Sampled T-Test), didapatkan adanya perbedaan signifikan antara GS dengan GO.

\section{Ucapan Terima Kasih}

Penulis mengucapkan terima kasih kepada seluruh narasumber, yaitu followers Instagram @tmcpoldametro yang bersedia mengisi kuisioner penelitian ini. Kemudian ucapan terima kasih juga diberikan kepada dosen pembimbing serta rekan-rekan diskusi di Fakultas Ilmu Komunikasi.

\section{Daftar Pustaka}

Asosiasi Penyelenggara Jasa Internet Indonesia (APJII). (2017). Infografis Penetrasi dan Perilaku Pengguna Internet Indonesia 2017. <https://apjii.or.id/survei2017〉. Diunduh tanggal 4 September 2018.

HypeAuditor. (2018). Instagram Audience Report of @ tmcpoldametro. $<$ https://hypeauditor.com/report/tmcpoldametro/>. Diunduh tanggal 11 November 2018.

Kriyantono, Rachmat. (2012). Teknik Praktis Riset Komunikasi. Cetakan ke-6. Jakarta: Kencana Prenada Media Group.

Ma'ruf, Moh. Ali. (2017). Analisa Penggunaan Instagram Sebagai Media Informasi Kabupaten Nganjuk (Studi Deskriptif Kualitatif pada founder dan followers @ nganjukkotabayu). UIN Sunan Kalijaga Yogyakarta.

McQuail, Denis. (2011). Teori Komunikasi Massa (Edisi 6, Buku 1). Jakarta: Salemba Humanika.

Megapolitan.kompas.com (6 Juni 2018). Distribusi Informasi TMC Polda Metro, dari "Call Center" Berevolusi ke Medsos". <https://megapolitan.kompas.com/read/2018/06/06/17484391/distribusiinformasi-tmc-polda-metro-dari-call-center-berevolusi-ke>. Diunduh tanggal 21 Januari 2019.

Nisfiannoor, M. (2013). Pendekatan statistika modern: Aplikasi dengan software dan e-views. Jakarta: Penerbit Universitas Indonesia.

Sugiyono. (2011). Metode Penelitian Kuantitatif, Kualitatif dan R\&D. Bandung: Alfabeta.

TechCrunch. (2018). Instagram hits 1 billion monthly users, up from 800M in September. <https://techcrunch.com/2018/06/20/instagram-1-billion-users/>. Diunduh tanggal 18 Januari 2019.

We Are Social. (2018). Digital in 2018 in Southeast Asia Part 2. <https://www.slideshare.net/wearesocial/digital-in-2018-in-southeast-asia-part2-southeast-86866464>. Diunduh tanggal 18 Januari 2019.

West \& Turner. (2013). Pengantar Teori Komunikasi: Analisis dan Aplikasi (Edisi 3, Buku 2). Jakarta: Penerbit Salemba Humanika.

Wibowo. (2015). Manajemen Kinerja. Jakarta: Rajawali Pers. 